\title{
Screening and identification of novel B cell epitopes of Toxoplasma gondii SAG1
}

Yanhua Wang ${ }^{1,3^{*}}$, Guangxiang Wang ${ }^{1,3}$, Delin Zhang ${ }^{1,2,3^{*}}$, Hong Yin ${ }^{1,3^{*}}$ and Meng Wang 2,3

\begin{abstract}
Background: The identification of protein epitopes is useful for diagnostic purposes and for the development of peptide vaccines. In this study, the epitopes of Toxoplasma gondii SAG1 were identified using synthetic peptide techniques with the aid of bioinformatics.

Findings: Eleven peptides derived from T. gondii SAG1 were assessed by ELISA using pig sera from different time points after infection. Four (PS4, PS6, PS10 and PS11), out of the eleven peptides tested were recognized by all sera. Then, shorter peptides that were derived from PS4, PS6, PS10 and PS11 were predicted using bioinformatics and tested by experimentation. Four out of nine shorter peptides were identified successfully (amino acids 106-120, 166-180, 289-300 and 313-332).

Conclusions: We have precisely located the epitopes of T. gondii SAG1 using pig sera collected at different time points after infection. The identified epitopes may be useful for the further study of epitope-based vaccines and diagnostic reagents.
\end{abstract}

Keywords: Toxoplasma gondii, SAG1, Epitope, Pig antibodies

\section{Findings}

Toxoplasma gondii is an obligate intracellular parasite that infects a variety of mammals and birds, causing toxoplasmosis $[1,2]$. T. gondii is an important food-borne parasite, and the primary route of transmission from animals to humans is through the consumption of infected meat $[3,4]$. In some countries, pork is the most common meat consumed, and some ethnic groups consume raw pork; thus, pigs are considered to be the primary source of human infection with $T$. gondii [5]. In addition, toxoplasmosis is a source of significant economic losses for swine farmers [6]. Therefore, the development of effective diagnostic reagents or vaccines for controlling this infection is required. Attempts to develop a peptide-based vaccine for T. gondii have focused on SAG1 and shown encouraging results [7]. Furthermore, the multiepitope antigen is one of the most promising antigens for the serodiagnosis of toxoplasmosis. Thus, it is very important to determine the

\footnotetext{
* Correspondence: wangyh061001@163.com; zhangd12005@163.com; yinhong@caas.net.cn

'State Key Laboratory of Veterinary Etiological Biology, Lanzhou 730046 China

${ }^{3}$ Lanzhou Veterinary Research Institute, Chinese Academy of Agricultural Sciences, Lanzhou 730046, China

Full list of author information is available at the end of the article
}

precise sequences against which effective immune responses are directed. SAG1 epitopes have been studied by different research groups [8-10]. However, it is still unclear which SAG1 peptides are recognized by antibodies from pigs infected with $T$. gondii. Therefore, B cell epitopes of SAG1 were analyzed using a synthetic peptide technique in combination with software-based prediction.

\section{Serum samples}

A total of $51 T$. gondii-positive sera, which had been previously collected from experimentally infected pigs by our lab, were investigated. Twelve pig serum samples were collected at the time of presentation of clinical symptoms (G1); 18 follow-up specimens were taken on days 14 to 35 after the onset of symptoms (G2), and 21 further serum samples were taken on days 60 to 120 after the onset of symptoms (G3). Toxoplasma IgM and IgG antibodies were confirmed by $T$. gondii lysate antigen-ELISA. The serum samples in G1 and G2 were positive for IgM and IgG against T. gondii. The serum samples in G3 were only positive for IgG against $T$. gondii. Ten sera that were negative for T. gondii IgM and IgG were used as controls. The experimental protocol was approved by the Ethical Committee of the Lanzhou

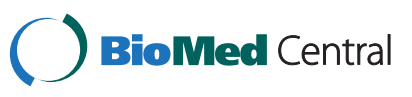


Table 1 Sequences of synthesized peptides

\begin{tabular}{|c|c|c|}
\hline Peptides & Start and end position & Sequence \\
\hline PS1 & $1-30$ aa & MSVSLHHFIISSGFLASMFPKAVRRAVTAG \\
\hline PS2 & $31-60$ aа & VFAAPTLMSFLRCGAMASDPPLVANQWTC \\
\hline PS3 & $61-90$ aа & PDKKSTAAVILTPTENHFTLKCPKTALTEP \\
\hline PS4 & $91-120$ aа & PTLAYSPNRQICPAGTTSSCTSKAVTLSSL \\
\hline PS5 & $121-150$ aа & IPEAEDSWWTGDSASLDTAGIKLTVPIEKF \\
\hline PS6 & $151-180$ aа & PVTTQTFWGCIKGDDAQSCMVTVTVQARA \\
\hline PS7 & $181-210$ aа & SSWNNVARCSYGANSTLGPVKLSAEGPTT \\
\hline PS8 & $211-240$ aа & MTLVCGKDGVKVPQDNNQYCSGTTLTGCNE \\
\hline PS9 & $241-270$ aа & KSFKDILPKLSENPWQGNASSDNGATLTIN \\
\hline PS10 & $271-300$ aа & KEAFPAESKSVIIGCTGGSPEKHHCTVQLE \\
\hline PS11 & $301-336$ aа & FAGAAGSAKSSAGTASHVSIFAMVTGLIGSIAACVA \\
\hline PS4-1 & $91-105$ aа & PTLAYSPNRQICPAG \\
\hline PS4-2 & $106-120$ aа & TTSSCTSKAVTLSSL \\
\hline PS4-3 & $100-114$ aа & QICPAGTTSSCTSKA \\
\hline PS6-1 & $151-165$ aа & PVTTQTFWGCIKGD \\
\hline PS6-2 & 159-173 аa & VGCIKGDDAQSCMVT \\
\hline PS6-3 & $166-180$ aа & DAQSCMVTVTVQARA \\
\hline PS10-1 & $271-305$ aа & KEAFPAESKSVIIGC \\
\hline PS10-2 & 281-294 aа & VIIGCTGGSPEKHH \\
\hline PS10-3 & 289-300 aа & SPEKHHCTVQLE \\
\hline PS11-1 & $301-315$ aа & FAGAAGSAKSSAGTA \\
\hline PS11-2 & 313-332 aа & GTASHVSIFAMVTGLIGSIA \\
\hline PS11-3 & $306-320$ aа & GSAKSSAGTASHVSI \\
\hline
\end{tabular}

Veterinary Research Institute, Chinese Academy of Agricultural Sciences.

\section{Synthetic peptides}

Based on the sequence of T. gondii SAG1 (Genbank Accession No. FJ455529), 20 non-overlapping or overlapping 12-36 mer peptides were synthesized by GL Biochem Ltd (Shanghai, China). Peptide sequences are shown in Table 1.

\section{ELISA analysis}

ELISA for each peptide were performed as described by Cardona et al. [10], except that microplates were coated with $10 \mu \mathrm{g} / \mathrm{ml}$ peptide and peroxidase-conjugated anti-pig IgG (1:4000) was used as the secondary antibody. PS1 was negative to all sera; PS2, PS3, PS5, PS7, PS8 and PS9 were recognized by few or partial sera (PS2: 5/51, PS3: $13 / 51$, PS5: 24/51, PS7: 32/51, PS8: 6/51 and PS9: 25/51), and only Four peptides (PS4, PS6, PS10 and PS11) were recognized by all sera (Figure 1). For each of the 4 peptides, no significant differences were observed between the mean absorbances of the three groups, as determined by an ANOVA statistical test. The mean absorbance \pm standard deviation of one peptide (amino acids 271-300) was significantly higher $(0.337 \pm 0.053)$ than that of the other peptides (PS4: $0.235 \pm 0.025, \mathrm{p}=0.000$; PS6: $0.237 \pm 0.0028$, $\mathrm{p}=0.000 ;$ PS11: $0.266 \pm 0.039, \mathrm{p}=0.001$ ). Five peptides (amino acids 61-80, 181-200, 241-260 and 301-320) derived from SAG1 were determined to be B cell epitopes, and one peptide (amino acids 301-320) was the peptide that was most strongly recognized by sera from patients with human ocular toxoplasmosis [10]. A robust immunological response to the SAG1 is associated with chronic Toxoplasma infection in humans [11]. However, we found that peptides derived from SAG1 were capable of being recognized by pig sera from different time points after infection, which is different from previous reports. The discrepancy could be explained by differences in parasite strains, by using different animal models as well as by the different MHC-types between human and pig.

\section{Precise definition of the epitopes}

To further determine the epitopes of SAG1 and decrease the number of laboratory experiments, bioinformatics was used to predict the epitopes. The secondary structure and the surface properties of the SAG1 were analyzed as described by Zhang [12]. The results are shown in Figure 2. Based on these results, 9 shorter peptides that were derived 

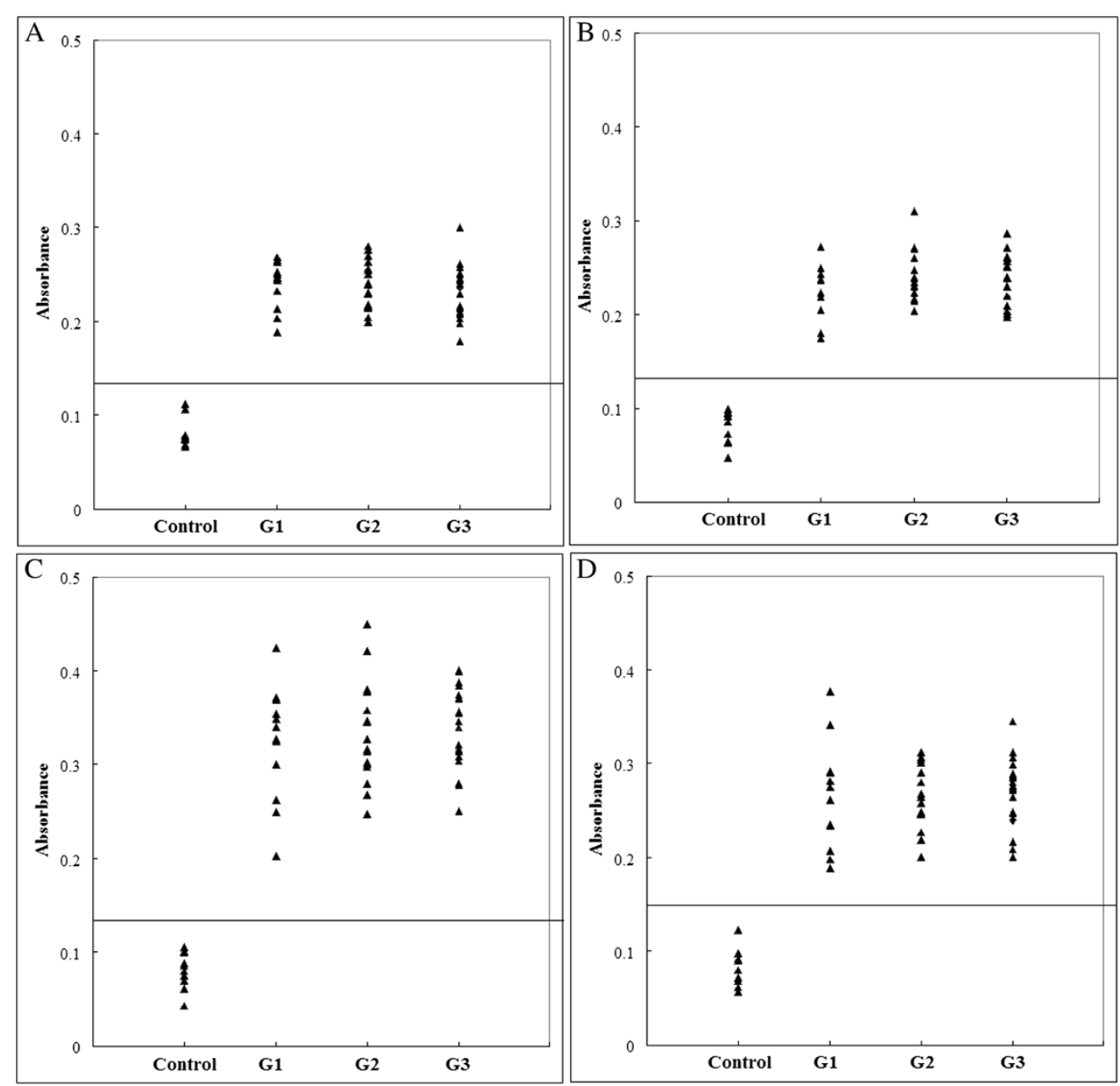

Figure 1 ELISA of IgG antibodies against different peptides in four groups of pig sera. (A), (B), (C) and (D) show the absorbances targeting to PS4, PS6, PS10 and PS11, respectively. The cut-off point for the assay is indicated by the horizontal line.

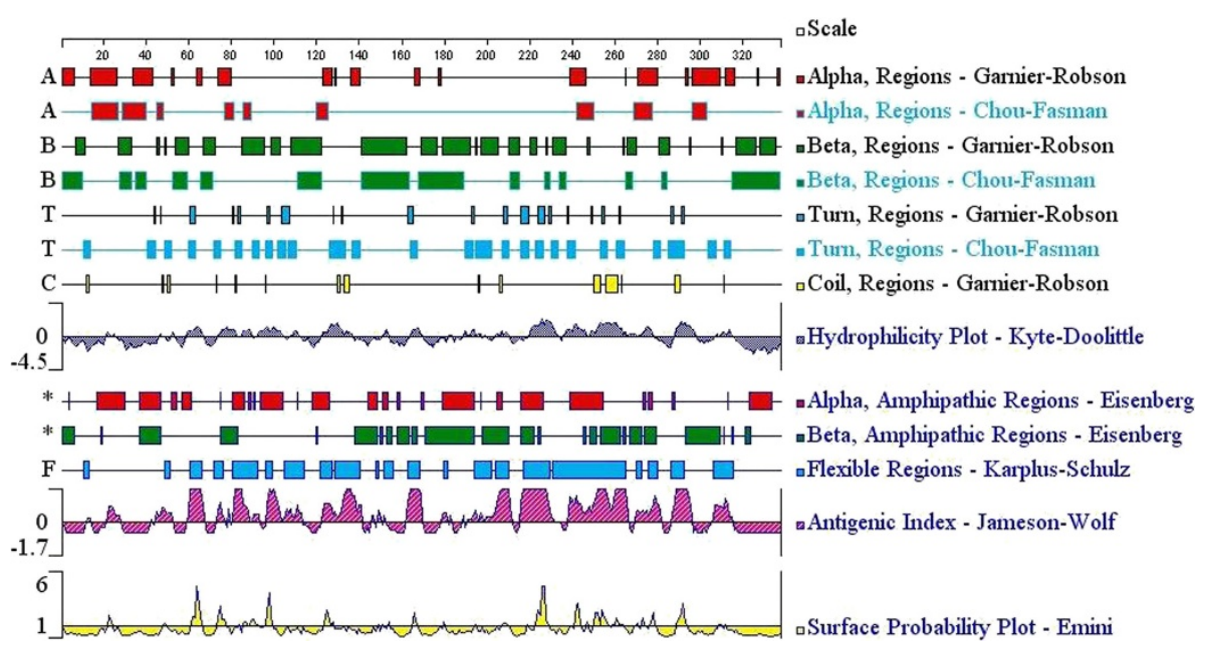

Figure 2 Secondary structures, flexibility, hydrophilicity, surface probability and antigenicity index for T. gongdii SAG1. 


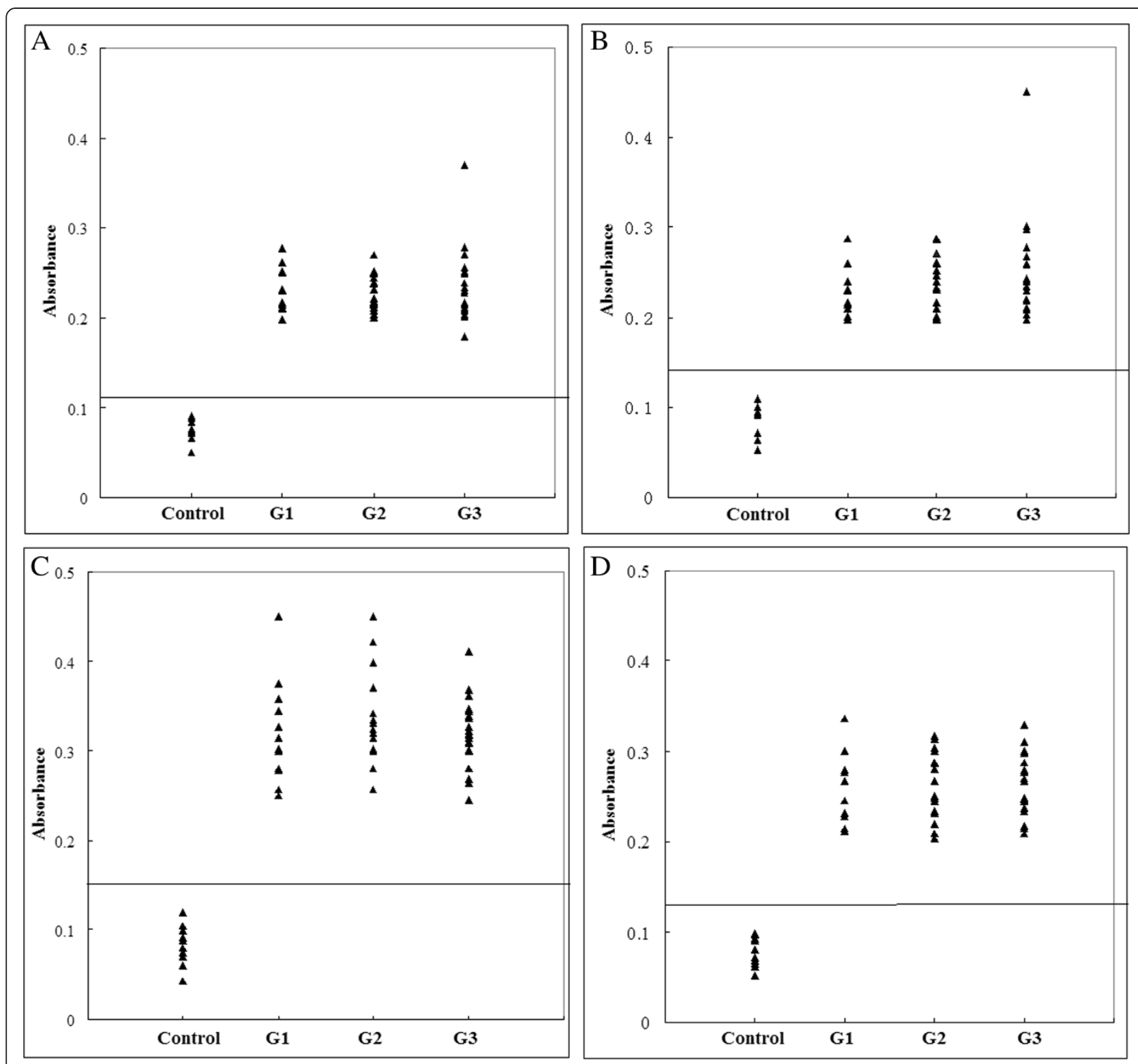

Figure 3 ELISA of IgG antibodies against different peptides in four groups of pig sera. (A), (B), (C) and (D) show the absorbances targeting to PS4-2, PS6-3, PS10-3 and PS11-2, respectively. The cut-off point for the assay is indicated by the horizontal line.

from PS4, PS6, PS10 and PS11 were chosen for further investigation (Table 1). These peptides were tested using pig sera as described above. Four out of 9 peptides (PS4-2, PS6-3, PS10-3 and PS11-2) were recognized by all sera. The results are shown in Figure 3.

\section{Conclusion}

Conformational epitope selection needs to determine the tertiary structure of antigen in order to identify antibody interacting residues in antigen. Experimental techniques such as crystallography are expensive and time consuming. Thus, our work focuses on linear epitope selection. In this study, we have located the epitopes of $T$. gondii SAG1 to a shorter sequence than had been identified previously. The identified epitopes will be useful in vaccine and diagnostic reagent design.

\section{Competing interests}

The authors declare that they have no competing interests.

\section{Authors' contributions}

YHW, HY and DLZ designed the experiment. YHW, GXW and MW performed lab work and drafted the manuscript. All the authors read and approved the final manuscript.

\section{Acknowledgments}

This investigation was supported by grants from the National Special Research Programs for Non-profit Trades (Agriculture) (200903036-02) and NBCITS, MOA (CARS-38). 


\section{Author details}

'State Key Laboratory of Veterinary Etiological Biology, Lanzhou 730046,

China. ${ }^{2}$ Key Laboratory of Veterinary Public Health of the Ministry of

Agriculture, Lanzhou 730046, China. ${ }^{3}$ Lanzhou Veterinary Research Institute,

Chinese Academy of Agricultural Sciences, Lanzhou 730046, China.

Received: 4 January 2013 Accepted: 26 April 2013

Published: 30 April 2013

\section{References}

1. Nardoni S, Angelici M, Mugnaini L, Mancianti F: Prevalence of Toxoplasma gondii infection in Myocastor coypus in a protected Italian wetland. Parasites Vectors 2011, 4:240.

2. Zhou P, Chen Z, Li HL, Zheng H, He S, Lin RQ, Zhu XQ: Toxoplasma gondii infection in humans in China. Parasit Vectors 2011, 4:165.

3. Boughattas S, Bergaoui R, Essid R, Aoun K, Bouratbine A: Seroprevalence of Toxoplasma gondii infection among horses in Tunisia. Parasites Vectors 2011, 4:218.

4. Yang N, Mu MY, Li HK, Long M, He JB: Seroprevalence of Toxoplasma gondii infection in slaughtered chickens, ducks, and geese in Shenyang, northeastern China. Parasites Vectors 2012, 5:237.

5. Wang M, Wang YH, Ye Q, Meng P, Yin H, Zhang DL: Serological survey of Toxoplasma gondii in Tibetan mastiffs (Canislupus familiaris) and yaks (Bos grunniens) in Qinghai, China. Parasites Vectors 2012, 5:35.

6. Sun XS, Zou J, Elashram Saeed AA, Yan WC, Liu XY, Suo X, Wang H, Chen QJ: DNA vaccination with a gene encoding Toxoplasma gondii GRA6 induces partial protection against toxoplasmosis in BALB/C mice. Parasites Vectors 2011, 4:213.

7. Wang $Y H$, Wang $M$, Wang GX, Pang AN, Fu BQ, Yin H, Zhang DL: Increased survival time in mice vaccinated with a branched lysine multiple antigenic peptide containing B- and T-cell epitopes from T. gondii antigens. Vaccine 2011, 29:8619-8623.

8. Velge-Roussel F, Chardès T, Mévélec P, Brillard M, Hoebeke J, Bout D: Epitopic analysis of the Toxoplasma gondii major surface antigen SAG1. Mol Biochem Parasitol 1994, 66:31-38.

9. Siachoque H, Guzman F, Burgos J, Patarroyo ME, Marin JEG: Toxoplasma gondii: Immunogenicity and protection by $\mathrm{P} 30$ peptides in a murine model. Exp Parasitol 2006, 114:62-65.

10. Cardona N, de-la-Torre A, Siachoque H, Patarroyo MA, Gomez-Marin JE: Toxoplasma gondii: P30 peptides recognition pattern in human toxoplasmosis. Exp Parasitol 2009, 123:199-202.

11. Jalallou N, Bandepour M, Khazan H, Haghighi A, Abdollahi SH, Kazemi B: Recombinant SAG1 antigen to detect Toxoplasma gondii specific immunoglobulin G in human sera by ELISA test. Iranian J Parasitol 2010, 5:1-9.

12. Zhang ZW, Zhang YG, Wang YL, Pan L, Fang YZ, Jiang ST, Lu JL, Zhou P: Screening and identification of $B$ cell epitopes of structural proteins of foot-and-mouth disease virus serotype Asia I. Vet Microbiol 2010, 140:25-33.

doi:10.1186/1756-3305-6-125

Cite this article as: Wang et al: Screening and identification of novel B cell epitopes of Toxoplasma gondii SAG1. Parasites \& Vectors 2013 6:125.

\section{Submit your next manuscript to BioMed Central and take full advantage of:}

- Convenient online submission

- Thorough peer review

- No space constraints or color figure charges

- Immediate publication on acceptance

- Inclusion in PubMed, CAS, Scopus and Google Scholar

- Research which is freely available for redistribution

Submit your manuscript at www.biomedcentral.com/submit
Ciomed Central 